\title{
On the collation of Books and Reference Materials Related to the Ideological and Political Theory Course under the Guidance of the Thoughts in the New Era
}

\author{
Zhong GUO \\ Shandong Technology and Business University \\ Yantai, 264005, Shandong
}

\begin{abstract}
XI Jinping's Thought on Socialism with Chinese Characteristics for a New Era is the heritance of other theoretical achievements of Marxism in adapting to Chinese conditions and is the theoretical foundation for the Party to lead the general public to achieve the great rejuvenation of the Chinese nation. The collation of books and reference materials related to the ideological and political theory course is an important part for propagating the Party's thoughts. The new era background requires us to make use of the advanced thoughts to guide the collation of books and reference materials related to the ideological and political theory course, so as to better guide the people to affirm their faith and beliefs, and carry out good ideological and political theory education for them.
\end{abstract}

Keywords-XI Jinping; Thought on Socialism with Chinese Characteristics for a New Era; Ideological and political theory education; Books and reference materials

\section{INTRODUCTION}

During the 19th National Congress, General Secretary XI pointed out, "Our Party is in a crucial period of securing a decisive victory in building a moderately prosperous society in all respects and striving for the great success of socialism with Chinese characteristics for a new era"[1]. In the most extensive and profound historical change in this history, the collation of books and reference materials related to the ideological and political theory course is a very important link for China's ideological and political construction in the new era. "How to integrate the Jinping XI Thought on Socialism with Chinese Characteristics for a New Era into the ideological and political education of colleges and universities timely and effectively, and complete the new mission and new requirements for the ideological and political work of colleges and universities in the new era"[2] is an issue that needs to be considered and solved urgently.

To achieve the great rejuvenation of the Chinese nation, it is necessary to lay a solid foundation for the cultivation of talents. As an important personnel training base in our country, colleges and universities must set ideological and political work as an important part in their teaching and education, which shall penetrate throughout the process of higher education and teaching. The ideological and political theory course needs to constantly absorb the nutrients of advanced ideas, proceed from reality, take the scientific thoughts as the orientation, take the practical experience as the guidance, and focus on solving the three key problems of what kind of person to cultivate, how to cultivate and for whom to cultivate. However, the collation of books and reference materials related to the ideological and political theory course in colleges and universities is the basis for the colleges and universities to carry out ideological and political education, and the preference of the collation of books and reference materials greatly affects the work orientation of ideological and political theory teaching. Only by using advanced ideas to guide the collation of books and reference materials related to the ideological and political theory course can we guide the younger generation to establish correct ideological and political ideas, cultivate their correct outlook on life and values, and lay a solid foundation for ideological and political education.

\section{Why XI's THOUght ON SOCIALISM WITH CHINESE}

CHARACTERISTICS FOR A NEW ERA IS USED TO GUIDE THE COLLATION OF BOOKS AND REFERENCE MATERIALS RELATED

\section{TO THE IDEOLOGICAL AND POLITICAL THEORY COURSE?}

Our country is in a key period of historical transition and the online and offline information in the new media era is numerous and complicated. "How to discard the falsehood and retain the truth, tell right from wrong, guide the students in a good way in the pluralistic social thoughts, and become the guider for students' all-round development" [4]and how to ensure "the safe transmission and saving of book information, and prevent information leakage caused by malicious damage of network" [5]. The collation of books and reference materials related to the ideological and political theory course is facing more difficult challenges than ever before and is shouldering the historical mission of inheriting the past and ushering into the future. Only under the guidance of the great theory and under the guidance of correct thought can our work inherit the legacy of Marxism- Leninism thought and usher in a new era, inherit the essence of Zedong MAO Thought and Xiaoping DENG Theory, and open the chapter of socialism with Chinese

CLC No.: G25 Document code: A 
characteristics, so as to better serve the development and prosperity of the whole society.

The ideological and political theory course in colleges and universities is an important part in the construction of spiritual civilization, and the collation of books and reference materials related to it plays an extremely guiding role; It shoulders the important historical mission of guiding the high-end talents represented by teachers and students in colleges and universities to read what books and how to read books.

The Jinping XI Thought on Socialism with Chinese Characteristics for a New Era can guide the collation of books and reference materials related to the ideological and political theory course, and the collation of books and reference materials related to the ideological and political theory course can also be useful to Jinping XI Thought on Socialism with Chinese Characteristics for a New Era to a certain extent. Through the collection and proper management of books and reference materials related to the ideological and political theory course, including the saving of audio and video, the people will have more selectivity and planning to acquire the essence of socialism in the new era, which will help popularize the new ideas among the masses. However, after Jinping XI Thought on Socialism with Chinese Characteristics for a New Era continues to be popularized in the whole society and spread to all levels, the masses pool the wisdom and efforts of the public to add new ideas, form new books and reference materials, help to Jinping XI Thought on Socialism with Chinese Characteristics for a New Era, and form a virtuous circle.

\section{WHY CAN XI'S THOUGHT ON SOCIALISM WITH CHINESE CHARACTERISTICS FOR A NEW ERA GUIDE THE COLLATION OF BOOKS AND REFERENCE MATERIALS RELATED TO THE IDEOLOGICAL AND POLITICAL THEORY COURSE?}

The management of books and reference materials related to the ideological and political theory course is different from the management of general books and reference materials and has stronger timeliness and guidance, which thus puts forward higher requirements for the management of books and reference materials related to the ideological and political theory course. To ensure the teaching and education quality of the ideological and political theory course in colleges and universities, the simple and feasible management mode under the guidance of scientific thought is the inevitable requirement for the efficient management of books and reference materials related to the ideological and political theory course. The history and the times has proved that the Party has led the people of all ethnic groups to achieve remarkable achievements in all dimensions and fields. It is the people's choice and the requirement of history to use Jinping XI Thought on Socialism with Chinese Characteristics for a New Era to guide the management work of books and reference materials related to the ideological and political theory course, which is also the only way for the development and progress of the books and reference materials management industry.

Jinping XI Thought on Socialism with Chinese Characteristics for a New Era is a scientific idea following the development law that the production relation must fit in with the development requirement of productivity. Using Jinping XI Thought on Socialism with Chinese Characteristics for a New Era to guide the collation work of books and reference materials related to the ideological and political theory course in colleges and universities has fundamentally eradicated the prevalence of "high index, blind command, boasting and exaggeration". It proceeds from the actual situation, combines theory with practice, takes lofty ideals as its guide, and steadily innovates on a down-to-earth basis. It solves the problem that some units and individuals blindly set the indicators, deviate from the actual production, take "the annual increase of the books and magazines", " the annual borrowing amount" and the" total inventory of the books and materials" as the only indicator to judge the work. Without strict review and examination, they purchase a large number of books and reference materials in order to reach the data of books and magazines and the total data of inventory books, thus resulting in a great waste of national resources.

Jinping XI Thought on Socialism with Chinese Characteristics for a New Era emphasizes people oriented and sets the fundamental interests of the overwhelming majority of the people as the goal, which has won the recognition and support of the people. The final service object of the collation of books and reference materials related to the ideological and political theory course in colleges and universities is the people as well. It is necessary to adhere to the people-oriented principle under the guidance of the ideological lighthouse of the new era, and strive to "train professional book and reference materials management personnel and strengthen the establishment of an intelligent management system"[6] under the premise of spreading positive social ideas. We should straighten out the mentality of the practitioners engaged in the collation of books and reference materials related to the ideological and political theory course, establish the peopleoriented working attitude, endeavor to serve teachers and students, and better contribute to the national ideological and political education.

The biggest difference between the collation of books and reference materials related to the ideological and political theory course and that of the traditional books and reference materials lies in its timeliness. The collation of books and reference materials related to the ideological and political theory course must conform to the development of the times and convey the latest thoughts of the Party and the State, which is one of the most important links for new ideas to spread to high-end talents. The most important requirement for the collation of books and reference materials related to the ideological and political theory course is to convey the most progressive and greatest thoughts of this era that keep up with the trend of the times to the people in the development era. The most progressive thought in this era is Marxism, the greatest thought is the thought on socialism with Chinese characteristics, and the thought that most keeps up with the trend of the times is Jinping XI Thought on Socialism with Chinese Characteristics for a New Era. However, the conveying work of great thoughts cannot be separated from the guidance of great thoughts. Only under the guidance of the Jinping XI Thought on Socialism with Chinese Characteristics for a New Era can the collation of books and reference materials related 
to the ideological and political theory course be carried out smoothly.

\section{HOW TO USE XI'S THOUGHT ON SOCIALISM WITH} CHINESE CHARACTERISTICS FOR A NEW ERA TO GUIDE THE COLLATION OF BOOKS AND REFERENCE MATERIALS RELATED TO THE IDEOLOGICAL AND POLITICAL THEORY COURSE?

\section{A. To breathe with the times and share the fate with the country}

When using Jinping XI Thought on Socialism with Chinese Characteristics for a New Era to guide the collation work of books and reference materials related to the ideological and political theory course, the first two basic issues to be clearly defined are what should be focused and what should be emphasized in the collation of books and reference materials for the ideological and political theory course. In other words, it is the question of what kind of information to be provided and how to provide information for the ideological and political theory course of teachers and students in colleges and universities. Since the 19th National Congress, the socialist development cause of our country has entered a completely new stage. The new era background puts forward new requirements for the collation of books and reference materials related to the ideological and political theory course. Only under the guidance of advanced thoughts, grasping the pulse of the times and conforming to the national development can the role of the collation of books and reference materials related to the ideological and political theory course be given into full play in the new era. Guided by the thoughts of the 19th National Congress, we should have a profound understanding of the spirit of the conference, " internalize it in the mind and externalize it into action", set the "Eight Clarities" and "Fourteen Upholdings" as the program, and comprehensively build a system for the management of the books and reference materials related to the ideological and political theory courses with the characteristics of socialism in the new era in an allround manner.

1) To improve the system of people's governance and development of socialist democracy

The socialist democracy with Chinese characteristics is the most extensive, true and dynamic democracy system since the emergence of the political system of human beings. All the power comes from the people, all the power belongs to the people, and all the power is used for the people. As an important link in the construction of socialist spiritual civilization, the collation of books and reference materials related to the ideological and political theory course serves the people and the socialist democracy. The application of Jinping XI Thought on Socialism with Chinese Characteristics for a New Era in the collation of books and reference materials related to the ideological and political theory course is to realize people's being the masters of the country under the leadership of the Party and manage the books and reference materials related to ideological and political theory course according to the laws and regulations. Restrain the practitioners by law and morality, and keep the power in the cage of the system; Follow the Party's leadership and obey the Party's arrangement; Listen to the opinions of all teachers and students extensively, listen to social suggestions and maintain communication with other universities to ensure smooth vertical and horizontal communication channels. To ensure that the collation of books and reference materials related to the ideological and political theory course correctly reflect the Party's policies and reflect the Party's thoughts; To ensure that the collation of materials is not separated from the masses and the actual situation, always put the actual needs of the masses in the first place, and do a good job in the management work of books and reference materials related to the ideological and political theory education in colleges and universities.

2) To enhance cultural confidence and help socialist culture to flourish

The Chinese nation inherits the soul of the Emperors Yan and Huang, and enlightens the Republic; It inherits the legacy of hundred schools of thought, and guides the socialism; The civilization has been inherited and spread for five thousand years. Our culture has the reason to be confident, has the capital to be confident, and needs to be confident. Thought on Socialism with Chinese Characteristics for a New Era has never been a single thought, and it is the essence collected from the thoughts of countless sages in the past five thousand years in China; Jinping XI Thought on Socialism with Chinese Characteristics for a New Era is definitely not groundless. It is the fruit rooted in the Chinese revolutionary wisdom; It is a systematic solution to the opportunities and challenges faced by contemporary China. Jinping XI Thought on Socialism with Chinese Characteristics for a New Era has solved a series of basic problems in the management work of books and reference materials related to the ideological and political theory course, such as how to distinguish the essence and dregs in culture, how to inherit the essence of culture adapted to the contemporary era, and how to spread the great theoretical achievement of Jinping XI Thought on Socialism with Chinese Characteristics for a New Era.

The primary condition for promoting the prosperity of socialist culture by the management of books and reference materials related to the ideological and political theory course is to build cultural confidence. Different from other industries, the administrators for the collation of books and reference materials related to the ideological and political theory course are not only the audience of socialist culture, but also the disseminators of socialist culture. Therefore, the administrators for the collation of books and reference materials related to the ideological and political theory course should not only strengthen their own cultural confidence, but also strengthen their sense of social responsibility and sense of mission to establish cultural confidence for teachers and students in colleges and universities, cultivate an atmosphere of cultural confidence in society, and lay a solid foundation for the Party to promote the prosperity of socialist culture.

Of course, cultural confidence does not mean cultural conceit, nor does not mean that the excellent cultural achievements of other countries and nations can be ignored. Jinping XI Thought on Socialism with Chinese Characteristics for a New Era guides us to incorporate things of diverse nature, adhere to the principle of "centering around ourselves and utilizing for our own benefits" and actively absorb the nutrition of human civilization. This warns that the administrators of 
books and reference materials related to the ideological and political theory course need to master the balance, turn the wisdom of people of all ethnic groups in modern or ancient times, in China or the foreign countries into their own use, and jointly serve socialism under the overall planning of Jinping XI Thought on Socialism with Chinese characteristics for a New Era. In other words, the administrators of books and reference materials should introduce the ideological and political writings of other countries and nationalities under the condition of not changing the fundamental thoughts so as to broaden the horizons and insights for the readers. Our culture is a culture of self - confidence, a culture that can stand the test of the times, and a culture of constant self - improvement and development. Under the guidance of Jinping XI Thought on Socialism with Chinese characteristics for a New Era, the administrators of books and reference materials related to the ideological and political theory course should not be afraid of the challenges and should not refuse to communicate, either. Only when the practitioners themselves have firmed their cultural confidence can they establish cultural confidence for the readers and further promote the prosperity of socialist culture.

\section{B. Staying committeed to the socialist construction under the leadership of the party}

1) To adhere to the Party's leadership in all work.

The management work of the books and reference materials related to the ideological and political theory course in colleges and universities must take the Party as the banner, take the will of the party as the will, closely surround the core, and adhere to the Party's leadership in all work. The administrators of books and reference materials related to the ideological and political theory course shoulder the important mission of disseminating the ideology and culture, which requires the practitioners to strengthen their political awareness, define political positions and strengthen political consciousness. At the same time, it is also necessary to help the teachers of the ideological and political theory course and all the students to grasp the lifeline of the political direction, establish correct political concepts and build a stable political position. Carry out the sharing work of the management of books and reference materials related to the ideological and political theory course, and deeply solve the key problems such as what kinds of ideological and political theory course should be read and how to read books, etc.

\section{2) To adhere to the new development ideas}

The changes and invariances of our country in the new era put forward new requirements for the management work of the books and reference materials related to the ideological and political theory course. Under the guidance of socialist ideology in the new era, the management work of the books and reference materials related to the ideological and political theory course in the new era should adhere to scientific development, unswervingly implement the development ideas of innovation, coordination, green, openness and sharing, and contribute to the socialist development of our country in the new era.
The innovation in the new development ideas not only refer to the real-time updating of books and reference materials, but also refer to the innovation in the management modes of the books and reference materials related to the ideological and political theory course, and the innovation in the management thoughts. With the development of the times and the progress of technology, the management of books and reference materials has now entered the era of big data, which is not only an innovation in technology, but also an innovation in management mode; The administrators of books and reference materials should master the new technological means, change the management modes, adhere to the new development ideas, and synchronously realize the progress in the management thoughts.

The new development ideas emphasize the coordinated development, which puts forward new requirements for the administrators of books and reference materials related to the ideological and political theory course. The management work of the books related to the ideological and political theory course should coordinate the contradiction between the limited borrowing resources and the urgent self-improvement demand of the general teachers and students, coordinate the contradiction of alternate collision between the new and old ideas in the new historical period, and coordinate the contradiction between the differences in people's cultural level.

The new green development ideas emphasize the protection of the ecological environment, which is not only the requirement of the party and the state, but also the social responsibility of all mankind. The administrators of books and reference materials related to the ideological and political theory course should respond to the Party's call actively, start from themselves, and use modern technology to realize paperless office and multimedia lending services.

In the development ideas for the new era, openness and sharing complement each other. "Learning alone without exchanges with others will lead to ignorance" [7]. The new era requires us to establish an open mind and cultivate the concept of development; Actively carry out intra-industry exchanges, actively listen to professional suggestions in relevant fields, integrate the whole industry into a whole, and serve the socialist construction in the new era.

\section{CONCLUSION AND PROSPECT}

Great times require great thoughts, and great times will inevitably give birth to great thoughts. In the great historical transition period of achieving the great rejuvenation of the Chinese nation, numerous administrators of books and reference materials related to the ideological and political theory course will be to contribute to the construction of socialist spiritual civilization in our country and the development of socialism in the new era under the guidance of Jinping XI Thought on Socialism with Chinese Characteristics for a New Era. 


\section{REFERENCES}

[1] Jinping XI. Report to the 19th National Congress of the Communist Party of China October 18, 2017

[2] Yuan CHEN. On the ways for integrating Jinping XI Thought on Socialism with Chinese Characteristics for a New Era to the ideological and political education in colleges and universities. Journal of Hunan Institute of Humanities Science and Technology 2018, 35(04): 1-5.

[3] Dan SHEN. On the historical starting point of socialism with Chinese characteristics. The Journal of CPC Yunnan Provincial Committee School. 2013, 14 (1): 46-49.

[4] Zaiping JING. The challenges and coping strategies faced by the teachers in the ideological and political theory course in the new media era. Journal of Mianyang Normal University. 2017, 36(12): 49-51.

[5] Wenying LIU. Analysis of reform and innovation ways for the management of books and reference materials. Information Recording Material. 2018, 19(2): 180-181.

[6] Fang CHEN. Research and Practice of Books and reference materials Information Management under Network Environment. Intelligence, 2017(22), 262.

[7] Sheng DAI. The Book of Rites and Learning in the Western Han Dynasty. 